\title{
Anti-Inflammatory, Anti-pyretic and Acute Toxicity Effects of n-Butanol Extract of Atractylis flava Desf in Rats
}

\author{
Melakhessou Mohamed Akram*, Benkiki Naima, Marref Salah Eddine, Bouzidi Soumia
}

\section{Melakhessou Mohamed Akram*, Benkiki Naima, Marref Salah Eddine, Bouzidi Soumia}

Laboratoire de Biotechnologie des Molécules Bioactives et de la Physiopathologie Cellulaire. Université de Batna-2, 05000, ALGERIE.

\section{Correspondence}

Melakhessou Mohamed Akram Laboratoire de Biotechnologie des Molécules Bioactives et de la Physiopathologie Cellulaire. Université de Batna-2, 05000, ALGERIE.

Phone no : +213 770202117

E-mail: akram_med@hotmail.fr

\section{History}

- Submission Date: 25-10-2017

- Review completed: 04-12-2017;

- Accepted Date: 14-03-2018

DOI : 10.5530/pj.2018.4.128

Article Available online

http://www.phcogj.com/v10/i4

\section{Copyright}

(c) 2018 Phcog.Net. This is an openaccess article distributed under the terms of the Creative Commons Attribution 4.0 International license.

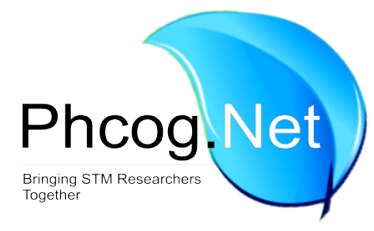

\begin{abstract}
Objectives: This study was aimed to explore the antipyretic and anti-inflammatory effects of $n$-butanol etract of Atractylis flava Desf (A. flava) using experimentally induced inflammation and pyrexia models in rats. Methods: In the acute toxicity study, a single oral dose of $2000 \mathrm{mg} / \mathrm{kg}$ of $n$-butanol extract was given to rats. The antipyretic activity was evaluated using brewer's yeast induced pyrexia in rats. In addition, albumin induced rat paw edema was performed by the injection of $100 \mu \mathrm{L}$ undiluted fresh egg albumin to assess the anti-inflammatory effects of the plant. Results: The results of the present study revealed that $n$-butanol extract of $A$. flava significantly $(P<0.001)$ reduced fresh egg albumin-induced rat paw edema and also inhibited fever significantly in brewer's yeast induced pyrexia. Conclusion: The results of the present study indicated that $A$. flava possesses antipyretic and anti-inflammatory activity in the models studied.

Key words: Atractylis flava desf, Pyrexia, Brewer's yeast, Egg albumin, Inflammation.
\end{abstract}

\section{INTRODUCTION}

The commonly used drugs for management of inflammatory and fever conditions are non-steroidal antiinflammatory drugs (NSAIDs), which have several adverse effects especially gastric irritation leading to formation of gastric ulcers. ${ }^{1}$ As an alternative, plantbased medicines are getting an increased therapeutics market share due to their mild action and fewer adverse effects. According to the World Health Organization nearly $80 \%$ of the world population prefers plant-based drugs. ${ }^{2}$ The wealth of plant kingdom can represent a current source of newer compounds with significant anti-inflammatory and antipyretic activities. The major merits of herbal medicines seem to be their perceived efficacy, low incidence of serious adverse effects, and low cost.

The species Atractylis flava Desf. Belongs to the genus Atractylis L. of the family Asteraceae (Compositae). ${ }^{3}$ This family, divided into 11 subfamilies and 35 tribes comprises about 1400 genera and more than 25.000 species of herbaceous plants, shrubs, and trees spread throughout the world. ${ }^{4,5}$ Atractylis plants are distributed worldwide but especially abundant in the Mediterranean zone. Atractylis flava Desf. (Syn. Atractylis carduus (Forsk.) locally called "assenan aouragh". Atractylis plants have been used in folk medicine to treat circulatory disorders, intestinal parasites, ulcers, and snake-bite poisoning, while A. flava was particularly known in traditional North African medicine for its diuretic effects. ${ }^{6,7}$ Phytochemical investigations of the whole plant revealed the presence of triterpenes, steroids, saponins and flavonoids. ${ }^{8}$ Furthermore, the presence of a tiliroside, narcissin, vicenin3, ladaneine and schaftoside was confirmed in the $n$-butanol extract of this plant. ${ }^{8,9}$ However, no data were found regarding the pharmacological evaluation of the plant. The aim of the present study is to evaluate the antiinflammatory and antipyretic properties of the n-butanol extract of the whole plant Atractylis flava Desf (BEAF).

\section{MATERIALS AND METHODS}

\section{Plant material}

The whole plant Atractylis flava Desf was collected from Biskra Algeria in the month of May 2015. The plant materiel was identified by Prof. Bachir Oudjehih (Agronomic Institute of Batna1 University, Algeria). A voucher specimen number (660/LCCE) was deposited in the herbarium of the mentioned department.

\section{Animals}

Experiments were performed using Wistar rats of both sexes, weighing $(150-180 \mathrm{~g})$. The animals were obtained from the Pasteur institute, Algiers, Algeria. The animals were kept in polypropylene cages under standardized conditions for 8 days before experiments. The animals were fed with standard diet and water ad libitum. 


\section{Extraction}

The collected whole plant Atractylis flava was air-dried and powdered. 500 g powder was macerated with $\mathrm{MetOH}-\mathrm{H}_{2} \mathrm{O}(80: 20)$. After filtration, the filtrate was concentrated under vacuum at room temperature the hydro alcoholic extract was submitted to liquid-liquid fractioning using solvents with increasing polarities (petroleum ether, dichloromethane, ethyl acetate, and $n$-butanol). The $n$-butanol fraction was used for the investigation of the acute toxicity study, anti-inflammatory and antipyretic effects.

\section{Acute toxicity study of the extract}

Acute oral toxicity study was performed as per the OECD-423 guidelines. ${ }^{10}$ Ten Wistar female rats were used for this study; they were divided into two groups of five animals each. The animals were fasted overnight and allowed free access to water, after A. flava $n$-butanol extract was administered orally in a single dose of $2000 \mathrm{mg} / \mathrm{kg}$ body weight. Animals were observed individually after dosing at least once every $30 \mathrm{~min}$, periodically during the first $4 \mathrm{~h}$, with special attention given during the first $24 \mathrm{~h}$.

General symptoms of toxicity and mortality in each group were observed within $24 \mathrm{~h}$. Animals that survived after $24 \mathrm{~h}$ were observed daily for any signs of delayed toxicity for two weeks. At the end of 14 days observation period, the animals were anaesthetized, and blood samples were collected through cardiac puncture with and without anticoagulant (EDTA) for hematological and biochemical analysis, respectively.

\section{Hematological analysis}

Hematological parameters: white blood cell (WBC), hemoglobin (HGB), red blood cell (RBC), hematocrit (HCT), mean cell volume (MCV), mean corpuscular hemoglobin $(\mathrm{MCH})$, mean corpuscular hemoglobin concentration (MCHC), lymphocyte \%, lymphocytes number (lymph no), Red cell distribution width (RDW), mean volume platelets of (VPM) and platelets (PLT)were determined using a hematology analyzer (ADVIA ${ }^{\otimes} 2120 \mathrm{i}^{\text {System}) .}$

\section{Biochemical analysis}

For biochemical parameters blood without additive was centrifuged at $3000 \times \mathrm{g}$ at $4^{\circ} \mathrm{C}$ for $10 \mathrm{~min}$, serum was separated and alanine aminotransferase (ALT), aspartate aminotransferase (AST), total bilirubin, urea, creatinine, glucose, HDL-Cholesterol, LDL-cholesterol, cholesterol and triglycerides were estimated using automated Analyzer (COBAS INTEGRA ${ }^{\oplus} 400$ plus).

\section{Egg albumin induced paw edema in rats}

The anti-inflammatory activity of the tested extract was evaluated in male Wistar rats by the egg albumin induced paw edema method. ${ }^{11}$ the animals were divided in five groups $(n=5)$.

All groups were kept fasting and allowed free access to water.

Group I was treated orally with normal saline $(10 \mathrm{~mL} / \mathrm{kg})$, group II with diclofenac $(30 \mathrm{mg} / \mathrm{kg})$, the rest of groups (III, IV and V) were treated with Atractylis flava $n$-butanol extract at the dose level of 100, 250 and $500 \mathrm{mg} / \mathrm{kg}$ p. o. After $1 \mathrm{~h}$, inflammation induced by sub plantar injection of $100 \mu \mathrm{L}$ of undiluted fresh egg albumin into the right hind paw of all rats. The paw thickness of each rat of all groups was measured in $\mathrm{mm}$ using digital vernier calipers at $0,1,2,3$, and $5 \mathrm{~h}$.

The percentage inhibition of edema by the tested extract and standard drug was calculated in comparison with vehicle control using this following formula:

$$
\% \text { inhibition }=\left[\frac{(\mathrm{tCn}-\mathrm{tC} 0)-(\mathrm{tTn}-\mathrm{tT} 0)}{(\mathrm{tCn}-\mathrm{tC} 0)}\right] \times 100
$$

Where $\mathbf{t} \mathbf{C n}=$ paw thickness at particular time point of control animal; $\mathbf{t C 0}=$ paw thickness before induction; $\mathbf{t} \mathbf{T} \mathbf{n}=$ paw thickness at particular time point of treated animal; and $\mathbf{t T 0}=$ paw thickness before induction.

\section{Brewer's yeast induced pyrexia}

Antipyretic activity was measured by Brewer's induced pyrexia in male Wistar rats. ${ }^{12}$ Rats were fasted overnight with free access to water before the experiments. Pyrexia was induced in animals by subcutaneous injection of $20 \%$ brewer's yeast $(10 \mathrm{~mL} / \mathrm{kg})$ suspended in saline solution into back side of below the nape of the neck. After $17 \mathrm{~h}$ of yeast injection, the rectal temperature of each rat was measured using a digital thermometer. Only rats that showed rectal temperature of $38^{\circ} \mathrm{C}$ and above were selected for the experiments. Rats were divided into five groups. The $1^{\text {st }}$ group was kept as a control (received the normal saline) while the $2^{\text {nd }}$ one was given paracetamol in a dose of $150 \mathrm{mg} / \mathrm{kg}$ (standard). The $3^{\text {rd }}$ - $5^{\text {th }}$ groups received orally 100,250 and $500 \mathrm{mg} / \mathrm{kg}$ of the BEAF, and the rectal temperature was measured periodically at $1,2,3$ and $5 \mathrm{~h}$ after drug administration.

\section{Statistical analysis}

Data were expressed as the mean \pm SEM. The data were analyzed using one-way analysis of variance (ANOVA) followed by Dunnett's test. Differences between two means were detected using the Student's t-test (acute toxicity test). Data were considered different at significance level of $\mathrm{p}<0.05$.

\section{RESULTS}

\section{Acute toxicity study}

The acute toxicity test revealed that the oral administration of a single dose $(2000 \mathrm{mg} / \mathrm{kg})$ of BEAF to rats did not bring any signs of toxicity or mortality in treated animals during the 14 days observation period. In addition, there was no significant difference in hematological and biochemical parameters between control and treatment group (Table 1 and 2). This indicates that BEAF was nontoxic in rats up to the dose of $2000 \mathrm{mg} / \mathrm{kg}$ of body weight (Table 1 and Table 2).

\section{Effect of the BEAF on egg albumin induced paw edema in rats}

The percentage rate of effect of BEAF in fresh egg albumin induced rat paw edema test and the average edema for the various groups was

\begin{tabular}{|c|c|c|}
\hline Biochemical parameters & Control & BEAF $2000 \mathrm{mg} / \mathrm{kg} \mathrm{BW}$ \\
\hline \multicolumn{3}{|c|}{ Liver profile } \\
\hline $\mathrm{AST}(\mathrm{U} / \mathrm{L})$ & $131 \pm 5.54$ & $122.8 \pm 3.36$ \\
\hline $\operatorname{ALT}(\mathrm{U} / \mathrm{L})$ & $86.2 \pm 7.13$ & $78.4 \pm 9.66$ \\
\hline Total bilirubin(mg/dL) & $0.76 \pm 0.04$ & $0.70 \pm 0.07$ \\
\hline \multicolumn{3}{|c|}{ Renal profile } \\
\hline Urea $(\mathrm{mg} / \mathrm{L})$ & $0.30 \pm 0.01$ & $030 \pm 0.01$ \\
\hline Creatinine $(\mathrm{mg} / \mathrm{L})$ & $4 \pm 0.01$ & $3 \pm 0.0$ \\
\hline \multicolumn{3}{|c|}{ Lipid profile } \\
\hline Cholesterol (mmol/L) & $0.57 \pm 0.04$ & $0.63 \pm 0.05$ \\
\hline Triglycerides (mmol/L) & $0.83 \pm 0.10$ & $1.14 \pm 0.15$ \\
\hline HDL-Cholesterol $(\mathrm{mmol} / \mathrm{L})$ & $0.50 \pm 0.03$ & $0.54 \pm 0.06$ \\
\hline LDL-Cholesterol ( $\mathrm{mmol} / \mathrm{L})$ & $0.06 \pm 0.01$ & $0.06 \pm 0.01$ \\
\hline Glucose (g/L) & $0.67 \pm 0.03$ & $0.68 \pm 0.05$ \\
\hline
\end{tabular}

Values are mean $\pm \operatorname{SEM}(n=5)$. No significant compared to control. 
Table 2: Hematological parameters of control and treated rats; measured during the acute toxicity study.

\begin{tabular}{|c|c|c|}
\hline $\begin{array}{l}\text { Hematology parameters } \\
\text { measured }\end{array}$ & Control & BEAF $2000 \mathrm{mg} / \mathrm{kg}$ BW \\
\hline $\mathrm{RBC}(106 \mathrm{x} \mu \mathrm{L})$ & $7.35 \pm 0.14$ & $7.13 \pm 0.06$ \\
\hline $\mathrm{MCV}(\mathrm{fL})$ & $55.68 \pm 0.85$ & $57.06 \pm 0.67$ \\
\hline RDW(fL) & $13.18 \pm 0.26$ & $13.22 \pm 0.25$ \\
\hline HCT (\%) & $40.92 \pm 0.48$ & $40.74 \pm 0.42$ \\
\hline $\operatorname{PLT}\left(10^{3} / \mu \mathrm{L}\right)$ & $614.8 \pm 61.76$ & $645.4 \pm 50.75$ \\
\hline MPV (fL) & $6.18 \pm 0.09$ & $6.32 \pm 0.13$ \\
\hline $\mathrm{WBC}\left(10^{3} / \mu \mathrm{L}\right)$ & $6.10 \pm 0.69$ & $6.92 \pm 1.10$ \\
\hline $\operatorname{HGB}(\mathrm{g} / \mathrm{dL})$ & $14.5 \pm 0.17$ & $14.34 \pm 0.11$ \\
\hline $\mathrm{MCH}(\mathrm{pg})$ & $19.74 \pm 0.25$ & $20.08 \pm 0.22$ \\
\hline $\mathrm{MCHC}(\mathrm{g} / \mathrm{dL})$ & $35.46 \pm 0.17$ & $35.22 \pm 0.13$ \\
\hline Lymphocyte no & $4.24 \pm 0.51$ & $4.82 \pm 0.93$ \\
\hline Lymphocyte \% & $69.08 \pm 2.43$ & $68.76 \pm 2.73$ \\
\hline
\end{tabular}

Values are mean $\pm \operatorname{SEM}(\mathrm{n}=5)$. No significant compared to control.
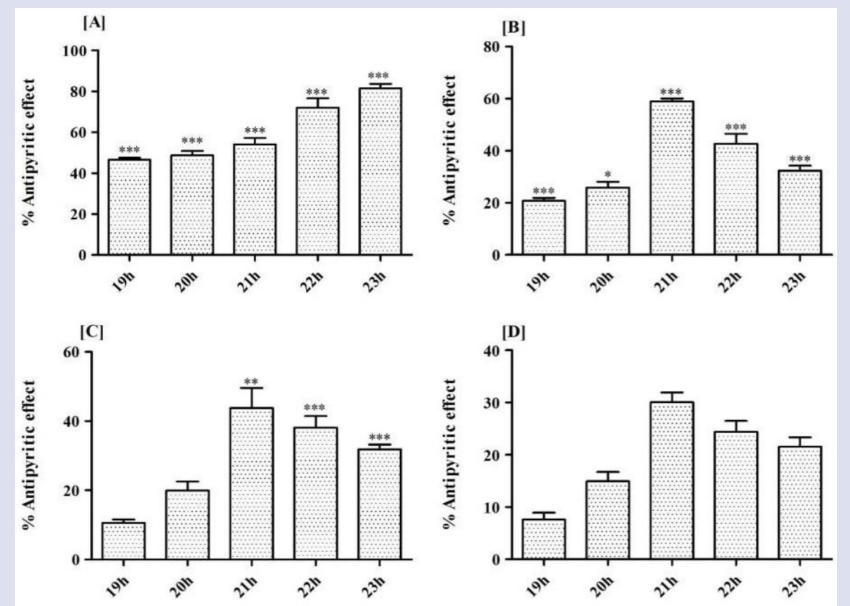

Figure 1: Percent of the antipyretic effect of BEAF in Brewer's yeast induced pyrexia test; [A]paracetamol, $150 \mathrm{mg} / \mathrm{kg}[B] 500 \mathrm{mg} / \mathrm{kg}$ and $[C] 250$ [D] $100 \mathrm{mg} / \mathrm{kg}$. Values are reported as mean \pm S.E.M $(n=5)$. ${ }^{*} \mathrm{P}<0.05,{ }^{* *} \mathrm{P}<0.01,{ }^{* * *} \mathrm{P}<0.001$ compared to control.

Table 3: Effect of the $n$-butanol extract of $A$. flava (BEAF) on egg albumin-induced paw edema in rats.

\begin{tabular}{cccccc}
\hline \multirow{2}{*}{$\begin{array}{c}\text { Treatment Dose } \\
(\mathrm{mg} / \mathrm{kg})\end{array}$} & \multicolumn{5}{c}{$\Delta$ paw edema $(\mathrm{m} \mathrm{m})$ and \% inhibition } \\
\cline { 2 - 5 } & $1 \mathrm{~h}$ & $2 \mathrm{~h}$ & $3 \mathrm{~h}$ & $4 \mathrm{~h}$ & $5 \mathrm{~h}$ \\
\hline Normal & $5.43 \pm 0.11$ & $4.92 \pm 0.21$ & $4.64 \pm 0.15$ & $4.09 \pm 0.17$ & $3.80 \pm 0.13$ \\
saline10(mL/kg) & & & & \\
BEAF 100 & $5.19 \pm 0.11$ & $4.46 \pm 0.21$ & $3.83 \pm 0.16^{* *}$ & $2.78 \pm 0.11^{* * *}$ & $2.35 \pm 0.10^{* * *}$ \\
& $(4.42 \%)$ & $(9.50 \%)$ & $(17.49 \%)$ & $(31.83 \%)$ & $(38.12 \%)$ \\
BEAF 250 & $5.02 \pm 0.09$ & $4.28 \pm 0.19$ & $3.66 \pm 0.15^{* * *}$ & $2.57 \pm 0.10^{* * *}$ & $1.79 \pm 0.06^{* * *}$ \\
& $(7.53 \%)$ & $(13.07 \%)$ & $(21.11 \%)$ & $(36.96 \%)$ & $(52.67 \%)$ \\
BEAF 500 & $4.76 \pm 0.10^{* *}$ & $3.89 \pm 0.17^{* *}$ & $3.18 \pm 0.08^{* * *}$ & $2.25 \pm 0.087^{* * *}$ & $1.61 \pm 0.05^{* * *}$ \\
& $(12.40 \%)$ & $(20.93 \%)$ & $(31.37 \%)$ & $(44.59 \%)$ & $(57.54 \%)$ \\
Dichlofenac 30 & $4.85 \pm 0.07^{* *}$ & $3.87 \pm 0.16^{* *}$ & $2.71 \pm 0.08^{* * *}$ & $1.94 \pm 0.07^{* * *}$ & $1.24 \pm 0.03^{* * *}$ \\
& $(10.65 \%)$ & $(21.43 \%)$ & $(41.59 \%)$ & $(52.31 \%)$ & $(67.28 \%)$ \\
\hline
\end{tabular}

Values are mean $\pm \operatorname{SEM}(\mathrm{n}=5) .{ }^{*} \mathrm{P}<0.05,{ }^{* *} \mathrm{P}<0.01,{ }^{* * *} \mathrm{P}<0.001$ compared to control.

demonstrated in (Table 3). Pre-treatment with BEAF exhibited significant anti-inflammatory activity during various assessment times $(1-5 \mathrm{~h})$ in a dose dependent manner. The highest inhibition of edema was obtained with $500 \mathrm{mg} / \mathrm{kg}$ dose $(57.54 \%)$ at the $5^{\text {th }}$ hour of drug administration. (Table 3).

\section{Antipyretic effect of BEAF in Brewer's yeast induced pyrexia test}

The results presented in Table 4 show that pyrexia was induced at 18 $\mathrm{h}$ after the injection of Brewers' Yeast to rats. The oral administration of BEAF $(500$ and $250 \mathrm{mg} / \mathrm{kg})$ significantly inhibited $(\mathrm{P}<0.01)$ hyperthermia induced by yeast. The antipyretic effect of BEAF $(500 \mathrm{mg} / \mathrm{kg})$ manifested from the $1^{\text {st }} \mathrm{h}$ and was remained significant up to $5^{\text {th }} \mathrm{h}$ of the post-treatment, while at the dose of $250 \mathrm{mg} / \mathrm{kg}$ the antipyretic effect appeared after $3 \mathrm{rd} \mathrm{h}$ of the treatment and remained significant up to 5 th h. A non-significant antipyretic effect at the dose $100 \mathrm{mg} / \mathrm{kg}$ was also observed. The percent pyrexia inhibition of all the tested groups is shown in (Figure 1)(Table 4).

\section{DISCUSSION}

Plants exhibit various pharmacological activities because of the presence of diverse kinds of constituents. It is compelling evidence that many chronic diseases such as inflammatory disorders, rheumatism, diabetes, cardiovascular and many neurodegenerative disorders have been treated by plants or their bioactive compounds used in the traditional medicine those can be a new therapeutic source for the treatment of chronic disorders. $^{13}$

The safety studies on medicinal plants were conducted by performing acute and sub-acute toxicity tests in laboratory animals. ${ }^{14}$ Acute toxicity study showed that the n-butanol extract of Atractylis flava Desf possessed high safety profile, as BEAF did not present noticeable signs of toxicity or mortality at the dose of $2000 \mathrm{mg} / \mathrm{kg}$, in any animal during the entire observation period. No significant differences on hematological and biochemical parameters when compared to the control group. These results indicated high margins of safety and explain the traditional use of the plant.

Egg albumin induced rat paw edema is one of a commonly used primary test to evaluate the anti-inflammatory effect of natural products. Edema formation results from the synergistic action of inflammatory mediators such as histamine, serotonin and bradykinin produced under the effect of cycloxygenase-2 (COX-2) at the site of a local inflammatory insult leading to increased vascular permeability and blood flow. ${ }^{15,16}$ Edema formation due to egg albumin in the rat paw is a biphasic event; the early phase of edema, which begins immediately after the administration of 
Akram, et al:: Anti-Inflammatory, Antipyretic and Acute Toxicity Effects of n-Butanol Extract of Atractylis flava Desf in Rats

Table 4: Antipyretic effect of BEAF in Brewer's yeast induced pyrexia test.

\begin{tabular}{ccccccccc}
\hline Treatment & Dose $(\mathrm{mg} / \mathrm{kg})$ & \multicolumn{6}{c}{ Rectal temperature in rats after drug administration } \\
\hline & & T0 & After $18 \mathrm{~h}$ & $19 \mathrm{~h}$ & $20 \mathrm{~h}$ & $21 \mathrm{~h}$ & $22 \mathrm{~h}$ \\
\hline Normal saline & $10(\mathrm{ml} / \mathrm{kg})$ & $36.56 \pm 0.23$ & $38.88 \pm 0.18$ & $38.74 \pm 0.17$ & $38.56 \pm 0.17$ & $38.32 \pm 0.12$ & $38.50 \pm 0.14$ & $38.56 \pm 0.15$ \\
& 100 & $36.16 \pm 0.12$ & $38.88 \pm 0.18$ & $38.74 \pm 0.17$ & $38.56 \pm 0.17$ & $38.32 \pm 0.12$ & $38.50 \pm 0.14$ & $38.56 \pm 0.15$ \\
\multirow{2}{*}{ BEAF } & 250 & $36.32 \pm 0.37$ & $39.36 \pm 0.04$ & $39.04 \pm 0.05$ & $38.82 \pm 0.05$ & $38.1 \pm 0.04^{* *}$ & $38.24 \pm 0.10^{* * *}$ & $38.38 \pm 0.12^{* * *}$ \\
& 500 & $36.08 \pm 0.21$ & $38.82 \pm 0.11$ & $38.24 \pm 0.09^{* * *}$ & $38.10 \pm 0.07^{*}$ & $37.22 \pm 0.09^{* * *}$ & $37.68 \pm 0.05^{* * *}$ & $37.94 \pm 0.06^{* * *}$ \\
& 150 & $35.96 \pm 0.23$ & $38.58 \pm 0.15$ & $37.36 \pm 0.14^{* * *}$ & $37.3 \pm 0.15^{* * *}$ & $37.15 \pm 0.09^{* * *}$ & $36.70 \pm 0.22^{* * *}$ & $36.44 \pm 0.22^{* * *}$ \\
\hline
\end{tabular}

Values are mean $\pm \operatorname{SEM}(\mathrm{n}=5) .{ }^{*} \mathrm{P}<0.05,{ }^{* *} \mathrm{P}<0.01,{ }^{* * *} \mathrm{P}<0.001$ compared to control.

the irritant and lasting up to $2 \mathrm{~h}$, is probably due to the release of histamine and serotonin. While the latter phase, occurring from 3 to $5 \mathrm{~h}$ after the administration of the irritant is induced by bradykinin, protease, prostaglandins and lysosome. ${ }^{17}$

The results of this study showed that BEAF significantly inhibited the formation of the paw edema during the first phase and significantly maintained in the second one. It can be suggested that this anti-inflammatory effect probably might be attributed to the inhibition of the release of pro-inflammatory mediators of acute inflammation, especially the prostaglandins.

Fever is a surrogate marker for disease activity in many infectious and inflammatory disorders. According to the classical view, the genesis of fever is induced by inflammatory mediators (i.e., cytokines, namely interleukin-1, interleukin-6, tumor necrosis factor, and others) that are predominantly released by activated peripheral mononuclear phagocytes and other immune cells. ${ }^{18,19}$ Antipyretic activity is commonly considered as a feature of drugs or compound which have an inhibitory effect on the biosynthesis or release of prostaglandins. ${ }^{20}$

The subcutaneous injection of brewer's yeast evoked pyrexia by ultimately increasing synthesis of prostaglandin and is considered as a valuable in vivo screening test for the assessment of antipyretic potential. ${ }^{21,22,23}$ The inhibition of prostaglandin synthesis could be the possible mechanism of antipyretic action as that of paracetamol and the inhibition of prostaglandin can be achieved by blocking the cyclooxygenase enzyme activity. ${ }^{24,25,12}$ The antipyretic effect of BEAF may be due to inhibiting the enzyme cyclooxygenase and reducing the level of prostaglandin within the hypothalamus in pyrexia rats.

Phytochemical study of the whole plant Atractylis flava showed abundance of flavonoids triterpenes, steroids, and saponins. Furthermore, the presence of a tiliroside, narcissin, vicenin 3, ladaneine and schaftoside were detected in the $n$-butanol extract. ${ }^{8,9}$

Flavonoids have been demonstrated that they are able to inhibit a series of enzymes, which are activated in the course of the inflammatory process. ${ }^{26}$ Also, flavonoid such as vicenin-2, Tiliroside, Schaftoside, have been recognized as potent inhibitors of pro-inflammatory mediators in different studies..$^{27,28,29,30}$ Anti-inflammatory and antipyretic action of BEAF may be due to the presence of above phytoconstituents. Hence, the effect may be due to the synergistic effect or than single constituent.

\section{CONCLUSION}

Based on the results of the current study, it could be confirmed that the $n$-butanol extract of $A$. flava contained secondary metabolites that showed outstanding anti-inflammatory and antipyretic activity. The plant therefore could be regarded as a natural source of anti-inflammatory and antipyretic compounds and could be used as an alternative remedy for treatment of inflammatory related disorders and disease. So, further studies are needed to identify and isolate the chemical constitu- ents responsible for these activities and to understand its mechanism of action.

\section{CONFLICT OF INTEREST}

The authors confirm that this article content has no conflict of interest.

\section{ACKNOWLEDGEMENT}

The authors wish to express thanks to the general directorate for scientific research and technological development (DGRSDT) of the Algerian Minister of Higher Education and Scientific Research for providing a research grant.

\section{ABBREVIATIONS}

BEAF: n-Butanol Extract of Atractylis flava Desf; MeOH: Methanol ; EDTA: Ethylene diamine tetraacetic acid.

\section{REFERENCES}

1. Tripathi KD. Essentials of medical pharmacology. New Delhi: Jaypee Brothers Medical Publishers Ltd. 2008:189.

2. Dharmasiri MG, Jayakody JRAC, Galhena G, Liyanage SSP, Ratnasooriya WD. Anti-inflammatory and analgesic activities of mature fresh leaves of Vitex negundo. 2003;87(2-3):199-206

3. Quezel P, Santa S. Nouvelle flore de l'Algérie et des régions désertiques méridionales. CNRS, Paris,France. 1963;(1-2).

4. Bremer K. Asteraceae: Cladistics and Classification. Timber Press, Portland. 1994.

5. Susanna A, Garcia-Jacas N, Hidalgo O, Vilatersana R, Garnatje T. The Cardueae (Compositae) revisited: insights from ITS, trnL-trnF, and matK nuclear and chloroplast DNA analysis. Ann. Missouri Bot. Gard. 2006;93(1):150-71.

6. Daniele C, Dahamna S, Firuzi O, Sekfali N, Saso L, Mazzanti G. Atractylis gummifera L. Poisoning: an ethnopharmacological review. J Ethnopharmacol. 2005;97(2):175-81.

7. El Rhaffari L, Zaid A. Pratique de la phytothérapie dans le sud-est du Maroc (Tafilalet). Un savoir empirique pour une pharmacopée rénoveé. Dans J. Fleurentin (éd.), Des sources du savoir auxmédicaments du futur, IRD editions, Paris. 293-318.

8. Chabani S, Lavaud C, Benkhaled M, Harakat D, Long C, Haba H. Three new oleanane-type triterpene saponins from Atractylis flava. Phytochem Lett. 2016:15:88-93.

9. Chabani S, Haba H, Lavaud C, Benkhaled M, Harakat D. Flavonoid glycosides and triterpenoids from Atractylis flava. Phytochem Lett . 2013;6(1):9-13.

10. Oecd/Ocde. Ligne directrice de l'ocde pour les essais de produits chimiques OCDE 301. 2013;(1):9

11. Anosike CA, Obidoa O, Ezeanyika LUS. The anti-inflammatory activity of garden egg (Solanum aethiopicum) on egg albumin-induced oedema and granuloma tissue formation in rats. Asian Pac J Trop Med. 2012;5(1):62-6.

12. Srinivas B, Kumar A, Lakshman $K, \mathrm{Kn}$ J. Comparative antipyretic activity of methanolic extracts of some species of Amaranthus. Asian Pac J Trop Biomed. 2011;1(1):S47-S50.

13. Jan S, Khan MR. Antipyretic, analgesic and anti-inflammatory effects of Kickxia ramosissima. JEthnopharmacol. 2016;182:90-100.

14. Fennell CW, Lindsey KL, McGaw LJ, Sparg SG, Stafford GI, Elgorashi EE, et al. Assessing African Medicinal plants for efficacy and safety: Pharmacological screening and toxicology. J Ethnopharmacol. 2004;94(2-3):205-17.

15. Kang HS, Lee JY, Kim CJ. Anti-inflammatory activity of arctigenin from Forsythiae fructus. J Ethnopharmacol. 2008;116(6):305-12. 
16. Begum S, Saxena B, Goyal M, Ranjan R, Joshi VB, Rao C V, et al. Fitoterapia Study of anti-inflammatory, analgesic and antipyretic activities of seeds of Hyoscyamus niger and isolation of a new coumarinolignan. Fitoterapia. 2010;81(3):178-84.

17. Wallace JM. Nutritional and botanical modulation of the inflammatory cascade: eicosanoids, cyclooxygenase and lipoxygenase-as an adjunct in cancer therapy. Integr Cancer Ther. 2002;1(1):7-37.

18. Zeisberger E. From humoral fever to neuroimmunological control of fever. J Therm Biol. 1999;24(5-6):287-26.

19. Roth J. Endogenous antipyretics. Clinica Chimica Acta. 2006;371(1-2):13-24.

20. Panthong A, Supraditaporn W, Kanjanapothi D, Tae sotikul T, Reutrakul V. Analgesic, anti - inflammatory and ventonic effects of Cissus quadrangularis Linn. J Ethnopharmacology. 2007;(110):264-70

21. Rauf A, Uddin G, Siddiqui BS, Khan A, Khan H, Arfan M, et al. In-vivo antinociceptive, anti-inflammatory and antipyretic activity of pistagremic acid isolated from Pistacia integerrima. Phytomedicine. 2014;21(12):1509-15.

22. Muhammad N, Saeed M, Khan H. Antipyretic, analgesic and anti-inflammatory activity of Viola betonicifolia whole plant. BMC Complement Altern Med. 2012;12(1):59.

23. Wan J, Gong X, Jiang R, Zhang Z, Zhang L. Antipyretic and anti-inflammatory effects of asiaticoside in lipopolysaccharide-treated rat through up-regulation of Heme Oxygenase-1. Phytother Res. 2013;27(8):1136-42.
24. Moltz H. Fever: Causes and consequences. Neurosci Biobehav Rev. 1993; 17:237-69.

25. Igbe I, Ozolua R, Okpo S, Obasuyi O. Antipyretic and analgesic effects of the aqueous extract of The fruit pulp of Hunteriaumbellata K. Schum (Apocynaceae). Trop J Pharm Res. 2009; 8(4):331-6.

26. Kwon KH, Murakami A, and Tanaka T, Ohigashi H: Dietary rutin, but not its aglyconquercetin, ameliorates dextran sulfate sodium-induced experimental colitis in mice: attenuation of proinflammatory gene expression. Biochem Pharmacol. 2005; 69(3):395-406.

27. Matsuda H, Ninomiya $K$, Shimoda H, Yoshikawa M. Hepatoprotective principles from the flowers of Tilia argentea (linden): structure requirements of tiliroside and mechanisms of action. Bioorg Med Chem. 2002;10(3):707-12.

28. Rao YK, Geethangili M, Fang SH, Tzeng YM. Antioxidant and cytotoxic activities of naturally Occurring phenolic and related compounds: a comparative study. Food Chem Toxicol. 2007:45(9):1770-6.

29. Dos Santos M, Chen G, Almeida M, Soares D, De Souza G, Lopes N, et al. Effects of caffeoylquinic acid derivatives and C-flavonoid from Lychnophorericoides on in vitro inflammatory Mediator production. Natural Product Communications. 2010;5(5):733-40.

30. Melo G, Muzitano M, Legora-Machado A, Almeida T, Oliveira D, Kaiser C, et al. C-glycosylflavones from the aerial parts of Eleusineindica inhibit LPS induced mouse lung inflammation. Planta Medica. 2005:71(4):362-3.

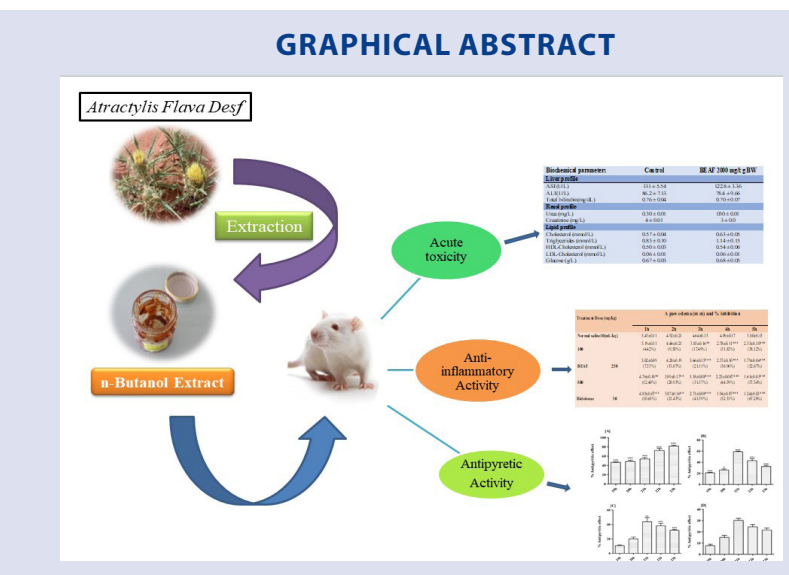

\section{SUMMARY}

- The present study has highlighted on the pharmacological investigation of the n-butanol extract of Atractylis flava Desf for the first time.

- $\quad$ The acute toxicity test revealed that BEAF was nontoxic in rats up to the dose of $2000 \mathrm{mg} / \mathrm{kg}$ of body weight.

- $\quad$ This study revealed that n-butanol extract of $A$. flava significantly reduced fresh egg albumin-induced rat paw edema and also inhibited fever significantly in brewer's yeast induced pyrexia.

- from the above results, we concluded that the n-butanol extract of Atractylis flava Desf have an anti-inflammatory and antipyretic activity.

\section{ABOUT AUTHORS}

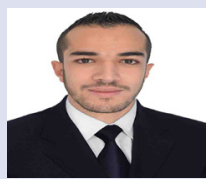

Mohamed Akram Melakhessou is currently a PhD student at University of Batna 02, ALGERIA.Biotechnology Laboratory of Bioactive Molecules and Cell Physiopathology.

Dr Naima Benkiki leads a research team in the Biotechnology Laboratory of Bioactive Molecules and Cell Physiopathology. University of Batna 02, ALGERIA.

Salah Eddine Marref is currently a PhD student at University of Batna 02, ALGERIA.Biotechnology Laboratory of Bioactive Molecules and Cell Physiopathology.

Soumia Bouzidi is currently a PhD student at University of Batna 02, ALGERIA.Biotechnology Laboratory of Bioactive Molecules and Cell Physiopathology

Cite this article: Akram MM, Naima B, Eddine MS, Soumia B. Anti-Inflammatory, Antipyretic and Acute Toxicity Effects of n-Butanol Extract of Atractylis flava Desf in Rats. Pharmacog J. 2018;10(4):763-7. 